\title{
AUTOMATIC IDENTIFICATION OF CAUSAL KNOWLEDGE AND CAUSAL GRAPHS IN TECHNICAL SYSTEMS OF PROCESS VENTILATORS
}

\author{
Senad Alić, Sabahudin Jašarević, Safet Brdarević, Mustafa Imamović, Indir Jaganjac
}

Preliminary notes

This research paper presents the approach of automated computerized identification of causal knowledge and causal graphs using monitoring of vibrations and temperatures of sliding bearings of high-power and high-speed process ventilators. Method of Granger causal connectivity analysis of vibration and temperature parameters is presented. This method improves diagnostics of process ventilators because of identification of causal relations and links of vibrations and temperatures in graph form. After computing and plotting causal graphs for vibrations and temperatures, causal density is computed as a measure of dynamical complexity of system. Numerical values of causal density are taken as indicators of systems "health" of process ventilators.

Key words: causal density; causal graph; Granger causal analysis; process ventilators; sliding bearings

Automatska identifikacija uzročnog znanja i uzročnih grafova u tehničkim sustavima procesnih ventilatora

Prethodno priopćenje

U ovom radu je dan pristup automatskog računarskog identificiranja uzročnog znanja i uzročnih grafova putem monitoringa vibracija i temperatura postrojenja procesnih ventilatora velikih snaga i velikih brzina vrtnje. Predstavljena je metoda Granger-ove uzročne analize uzročnih veza mjernih parametara vibracija i temperature. Ova metoda poboljšava dijagnostiku procesnih ventilatora zbog identifikacije uzročnih zakonitosti parametara vibracija i temperatura u dijagramskom obliku. Nakon računanja i crtanja uzročnog grafa za vibracije i temperature, računa se uzročna gustoća, kao mjera dinamičke složenosti sustava. Numeričke vrijednosti uzročne gustoće se uzimaju kao indikatori sustavnog "zdravlja" procesnih ventilatora.

Ključne riječi: Granger-ova uzročna analiza; klizni ležajevi; procesni ventilator; uzročni graf; uzročna gustoća

\section{Introduction}

Process ventilators (power $P=2,5 \mathrm{MW}, n=1500$ $\mathrm{rpm}$ ) are significant technical systems and one of the most important parts of sinter machines which represent major facility in the process of sinter production (sinter is the main component in Blast furnance production process). The function of ventilators is to enable burning (sintering) of sinter in sinter machines and dedusting of facilities by sucking of fumes and cleaning in electro filters. In this paper, ventilators are indicated by numbers, as 4, 5 and 6 . In the line with today's development of informatics, computer and measuring techniques, there is a question raised: 'how to use that development from the aspect of maintenance and timely detection of real status of process ventilators?'. Using of continuous monitoring and informatics should provide information about the condition of process ventilators, complex technical systems. This paper gives one way of calculation of process ventilators condition through the usage of online software for this type of analysis. Different types of process ventilators are used in industry and they are divided into groups based on: their purpose/ use, working pressure, operation and construction. Process ventilators (type $6500-\mathrm{II}-4$ ) which were tested for the purpose of this paper, are centrifugal ventilators which are constructed in "Novska tvornica strojeva" V. I. Lenjin, SSSR (ex Soviet Union). The basic parameters of these process ventilators are:

- capacity of wet gas in relation to basic conditions $6500 \mathrm{~m}^{3} / \mathrm{min}$,

- capacity of dry gas in relation to $0{ }^{\circ} \mathrm{C}$ and 1 bar on mercury scale $3680 \mathrm{~N} \cdot \mathrm{m}^{3} / \mathrm{min}$,

- number of process ventilator rotor rotations 1500 rpm,
- synchronous el. motor, type 140/74-4, power 2500 $\mathrm{kW}$, voltage $6000 \mathrm{~V}$, closed with air cooling system, - process ventilator rotor torque on el motor coupling $6550 \mathrm{~kg} \cdot \mathrm{m}^{2}$

Process ventilators 4, 5, 6 have 4 bearing housings with slide bearings (el motor relines on two slide bearings and ventilator rotor on two as well). The following parameters are being continuously measured on all bearings:

- temperature of slide bearings TT4101, 4102, 4201, 4202, 5101, 5102, 5201, 5202, 6101, 6102, 6201, 6202 , temperature of fumes on the entrance to process ventilators $4,5,6$

- TT4131, 5131, 6131, temperature of water for motor cooling in the system of air cooling of process ventilator 4, 5, 6 TT4121, 5121, 6121, temperature of oil for lubrication of slide bearings on the entrance into cooler which is cooled by water for process ventilators $4,5,6$

- TT4112, 5112, 6112, temperature of oil behind the cooler which is cooled by water for process ventilators 4,5,6, TT4111, 5111, 6111,

- vibrations on bearings VT 4211, 4212, 4213,4214, $5211,5212,5213,5214,6211,6212,6213,6214$, for slide bearings of process ventilators $4,5,6$,

- fumes pressure on the entrance into process ventilators 4, 5, 6 PT 4171, 5171, 6171.

Sensors for continuous measuring of temperature and vibrations are placed on slide bearings of process ventilators. Results of temperature and vibration measurements for the period from 1.5.2010 to 1.3.2012 for all three process ventilators are recorded. Temperature and vibrations sampling interval is 60 minutes. Three matrices are recorded $16083 \times 8(16083$ 
measuring values in 8 variables). These three matrices are input to Matlab program for automatic identification of Granger causal graphs for all three process ventilators.

Fig. 1 shows vertical section of one sinter machine (with its integral parts) as a complex technical system, and all ancillary equipment and continuous monitoring points. This type of arrangement of installed sensor for parameters monitoring is the same on all three sinter machines.

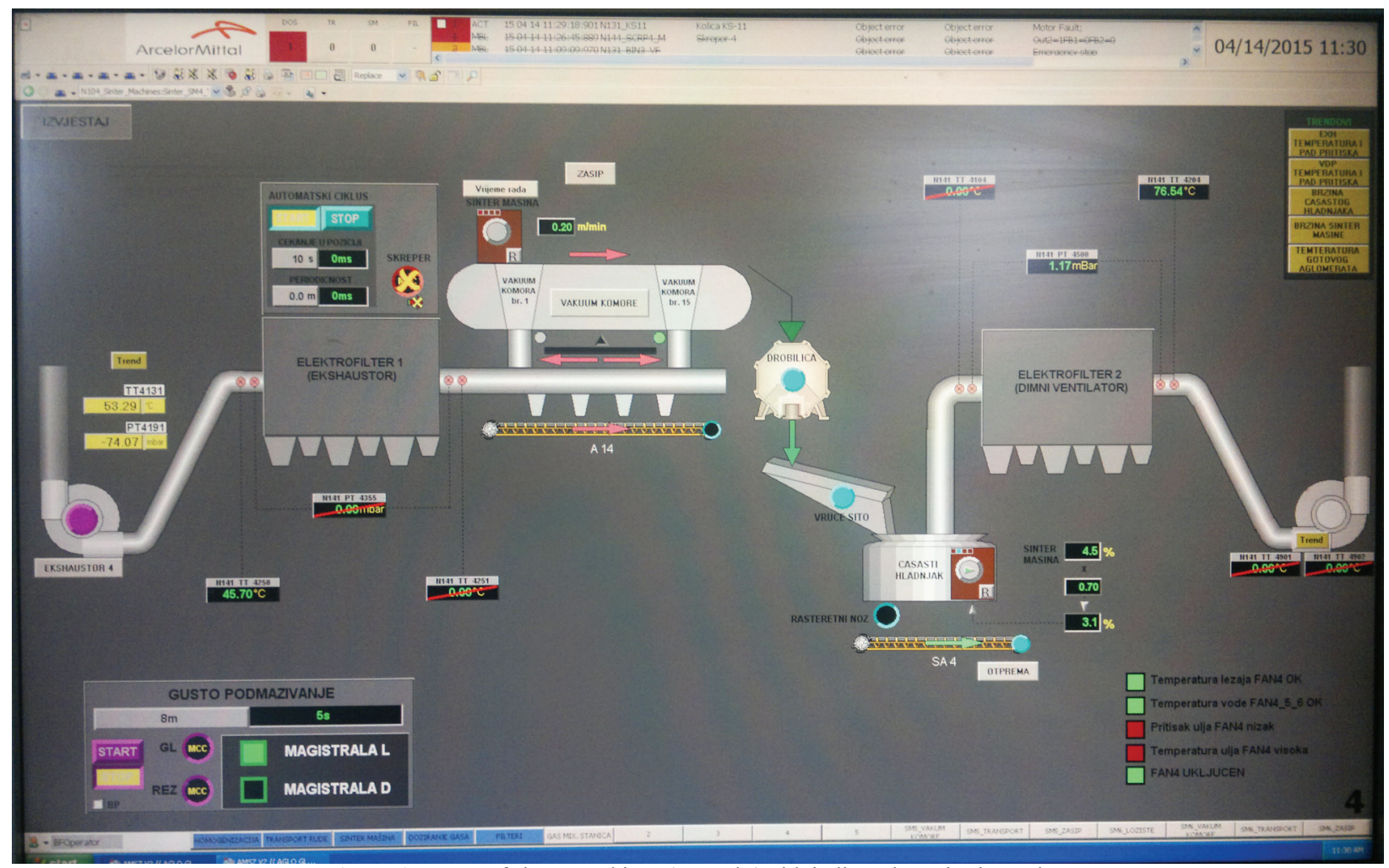

Figure 1 Layout of sinter machines 4, 5 and 6 with indicated monitoring points

Fig. 2 below shows three ground plans of process ventilators 4,5 and 6 on sinter machines 4,5 and 6 as well as arrangement (position) of installed sensors which serve for continuous monitoring of parameters.
Fig. 3 shows vibro-diagnostic monitoring of continuous parameters measuring on process ventilators which are the subject of analysis in this paper. Figs. 4, 5 and 6 show diagrams with temperature and vibrations of these process ventilators.

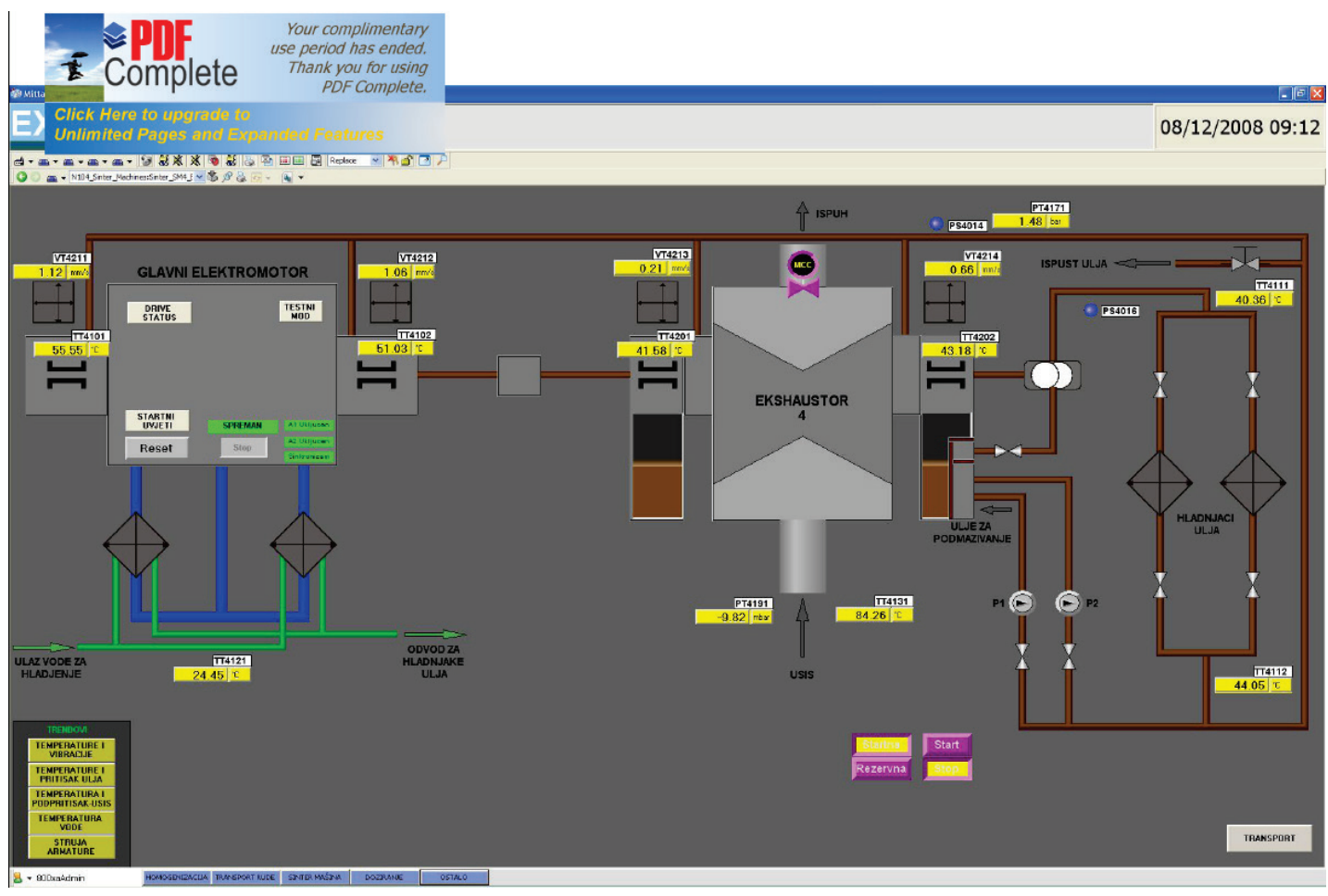



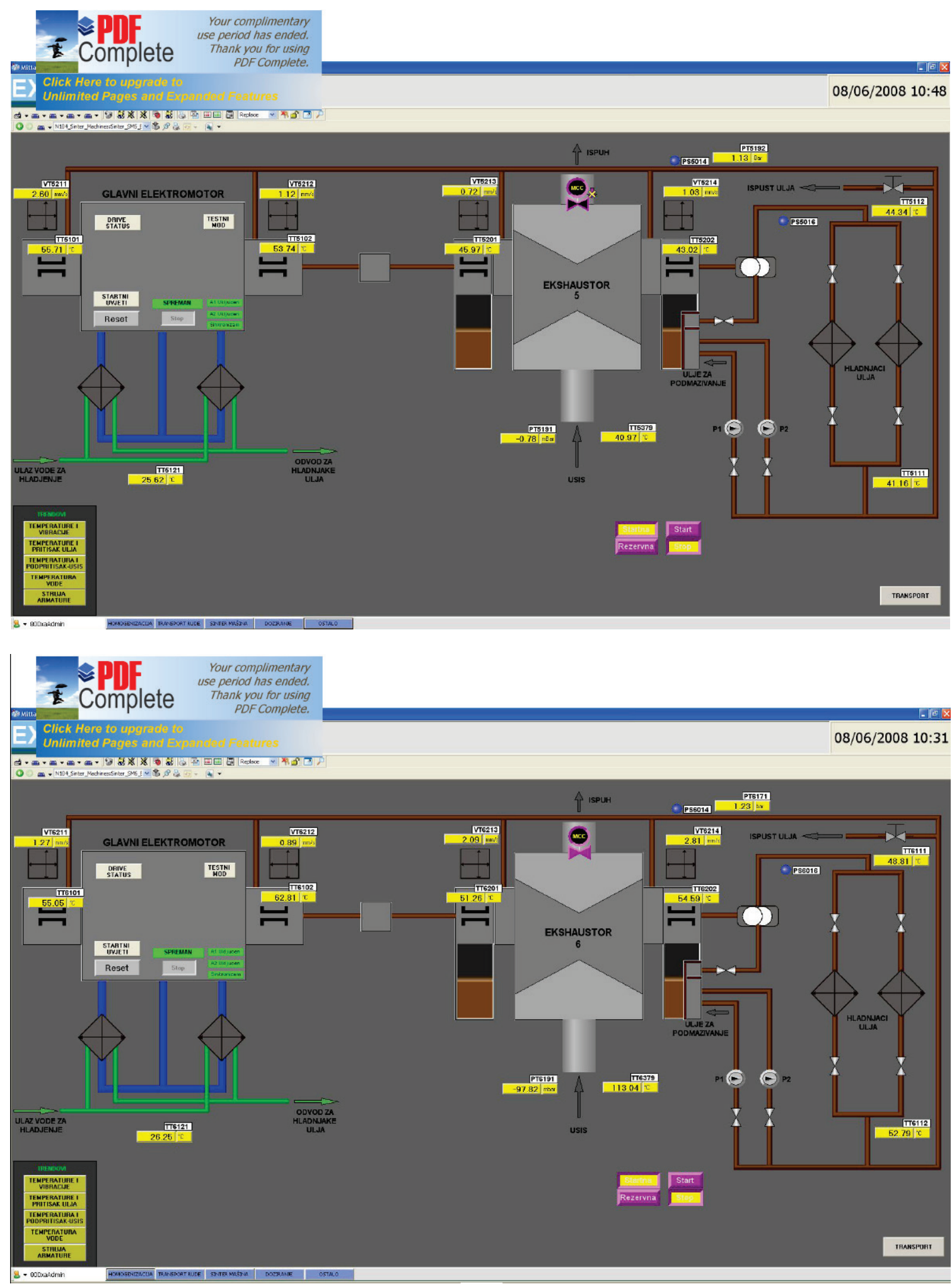

Figure 2 Schematic layout of process ventilators 4,5 and 6 with indicated parameters monitoring points

By means of mathematical model, Granger, this paper gives insight into interrelation and influence of temperature and vibration between slide bearings of el motor and impellor (rotor) on process ventilators. By observation of all technological and technical parameters of complex technical systems such as process ventilators, we can notice interrelation between continuously measured values. This type of analysis is possible to be performed on technical systems which have installed software for continuous monitoring of all important parameters. These parameters are regularly being tracked via one or more computers which are interconnected and located in control rooms (OPC-operating centers). These parameters are regularly stored in computer memory and later can serve for different types of analysis and estimations of process ventilators condition. Vibration and temperature signals, in duration of 3600 seconds, which are coming from vibration and temperature sensors are taken from ABB Industrial ${ }^{\mathrm{TT}}$ 800xA HMI. Type of vibration sensors is ProvibTech TM016. Output goes from $4 \div 20 \mathrm{~mA}$ which is proportional to vibrations on the machine. Vibration sensor TM016 measures the speed of 
vibration change in $\mathrm{mm} / \mathrm{s}$. Continuous monitoring of condition of rotating machines (stationary or nonstationary) by the method of vibration and temperature measurement has two significant aspects: monitoring of this type gives an opportunity for timely detection of irregularities on these expensive machines, possibility to plan maintenance costs and savings by avoiding of breakdowns and work interruptions. This method also improves workers' safety and proactively prevents problems and emergency situations.
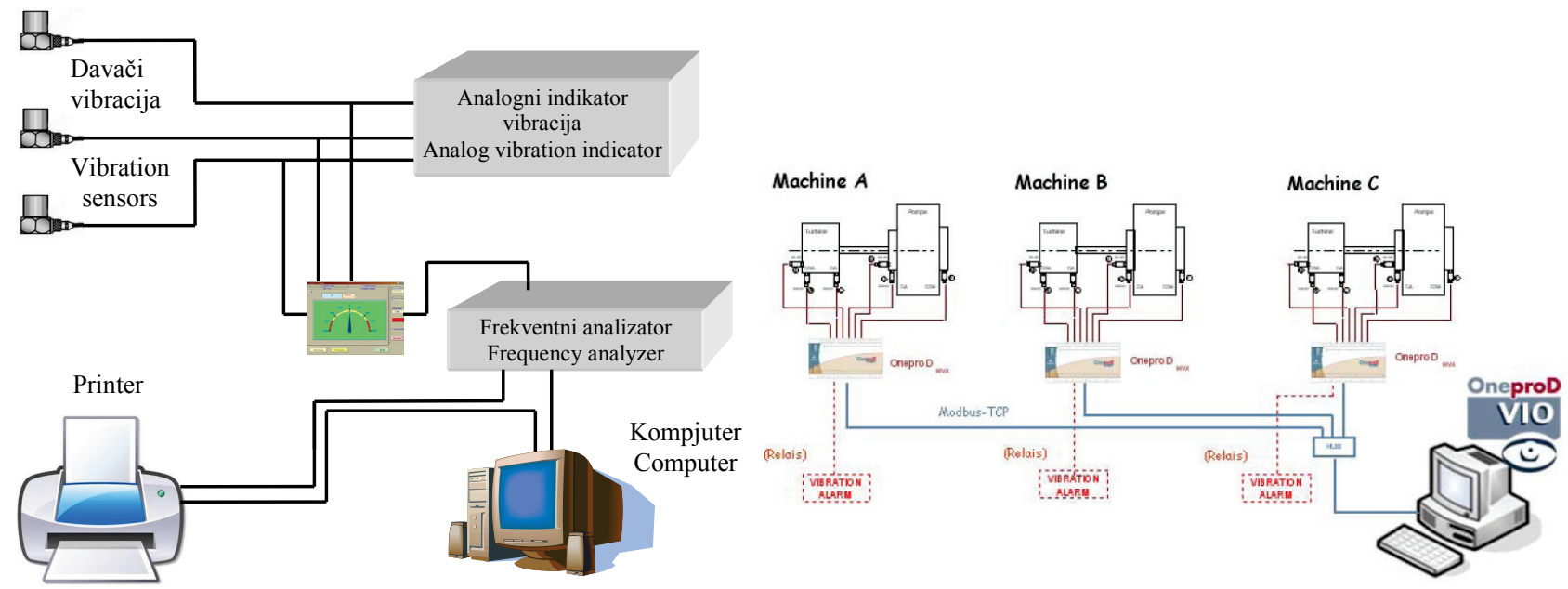

Figure 3 Vibro-diagnostic monitoring of vibrations and temperature of process ventilators bearings



Figure 4 Vibrations and temperatures on four slide bearings on process fan 4 during one day

Temperature, vibrations and pressure signals are taken continuously in analogue manner and they are converted into digital signals by suitable automatic devices. Temporal display (Figs. 4, 5 and 6) of vibration and temperature signals can indicate development of early breakdowns on process ventilators bearings. Fig. 7 . presents current and speed of vibration change. Diagnostics of early breakdowns on bearings is done in two classes: normal operation and early breakdown (anomaly). If vibrations on diagrams are in interval from $0 \div 8,2 \mathrm{~mm} / \mathrm{s}$, ventilator will continue to work but optimal vibration values are $2,5 \div 3 \mathrm{~mm} / \mathrm{s}$. If temperature values are between $0 \div 72{ }^{\circ} \mathrm{C}$, ventilator will continue to work but optimal temperature is $30 \div 40{ }^{\circ} \mathrm{C}$. Sub-pressure on the entrance into exhauster goes from $55 \div 160$ mbar. A message on PC for optimal operational parameters will be "nominal operation". If temperature, vibration and pressure values are not in optimal work regime, then the message will indicate "failure".

\section{Mathematical model of Granger's causal analysis}

In 1969 Clive Granger introduced a definition of Gcasualty, as a formal description of Wiener's hypothesis: $\mathrm{X}_{2}$ causes $\mathrm{X}_{1}$ if knowledge about $\mathrm{X}_{2}$ helps to anticipate $\mathrm{X}_{1}$ $[2,3,6,7,8]$. According to definition of G-casualty, $X_{2}$ 
causes $\mathrm{X}_{1}$, if introduction of previous observations of $\mathrm{X}_{2}$ decreases errors in anticipation of $\mathrm{X}_{1}$, in linear regressive and predictive model $\mathrm{X}_{1}$ and $\mathrm{X}_{2}$. Inverse system identification sets significant and fundamental problem:

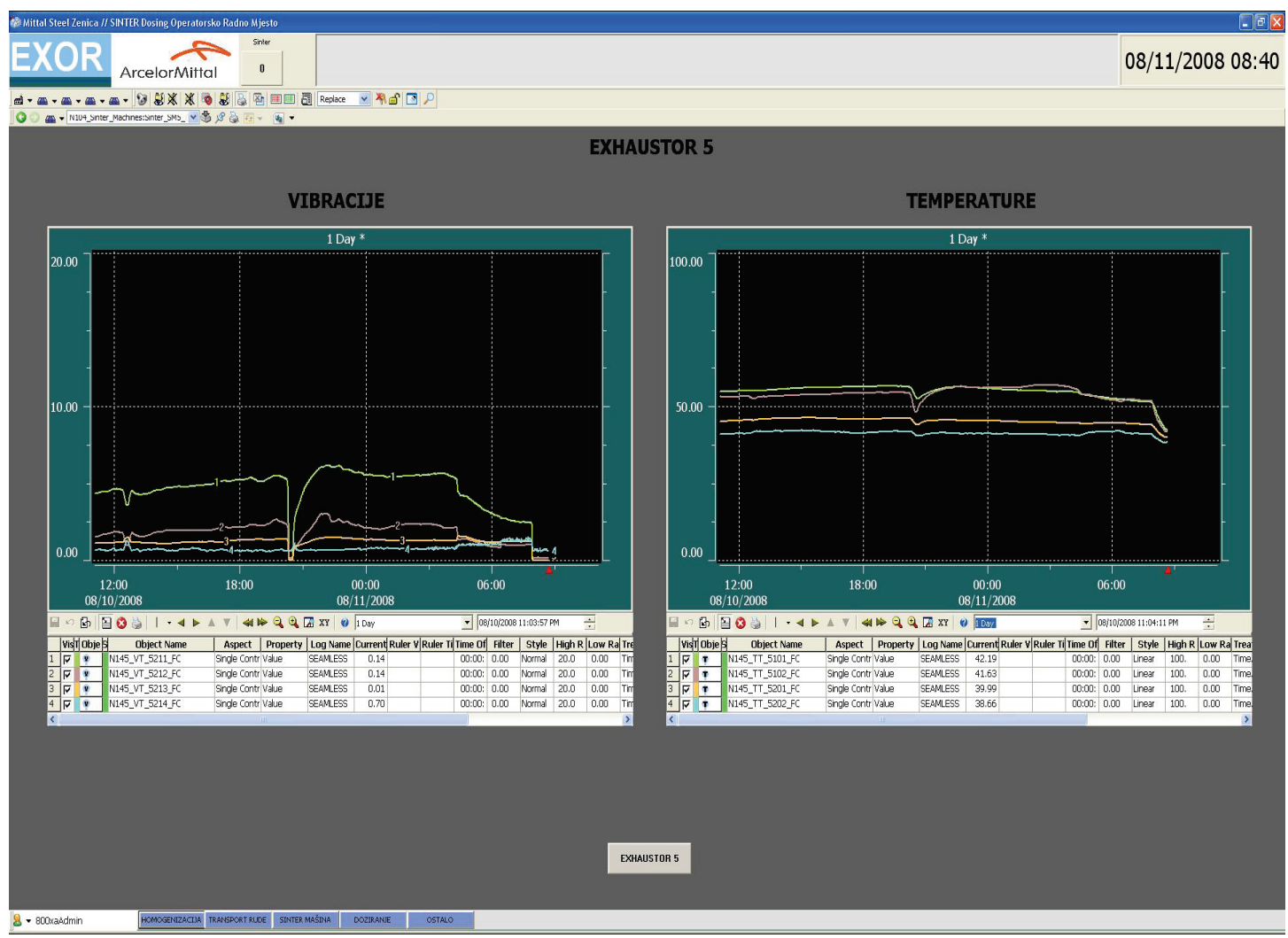

Figure 5 Vibrations and temperatures on four slide bearings on process fan 5 during one day

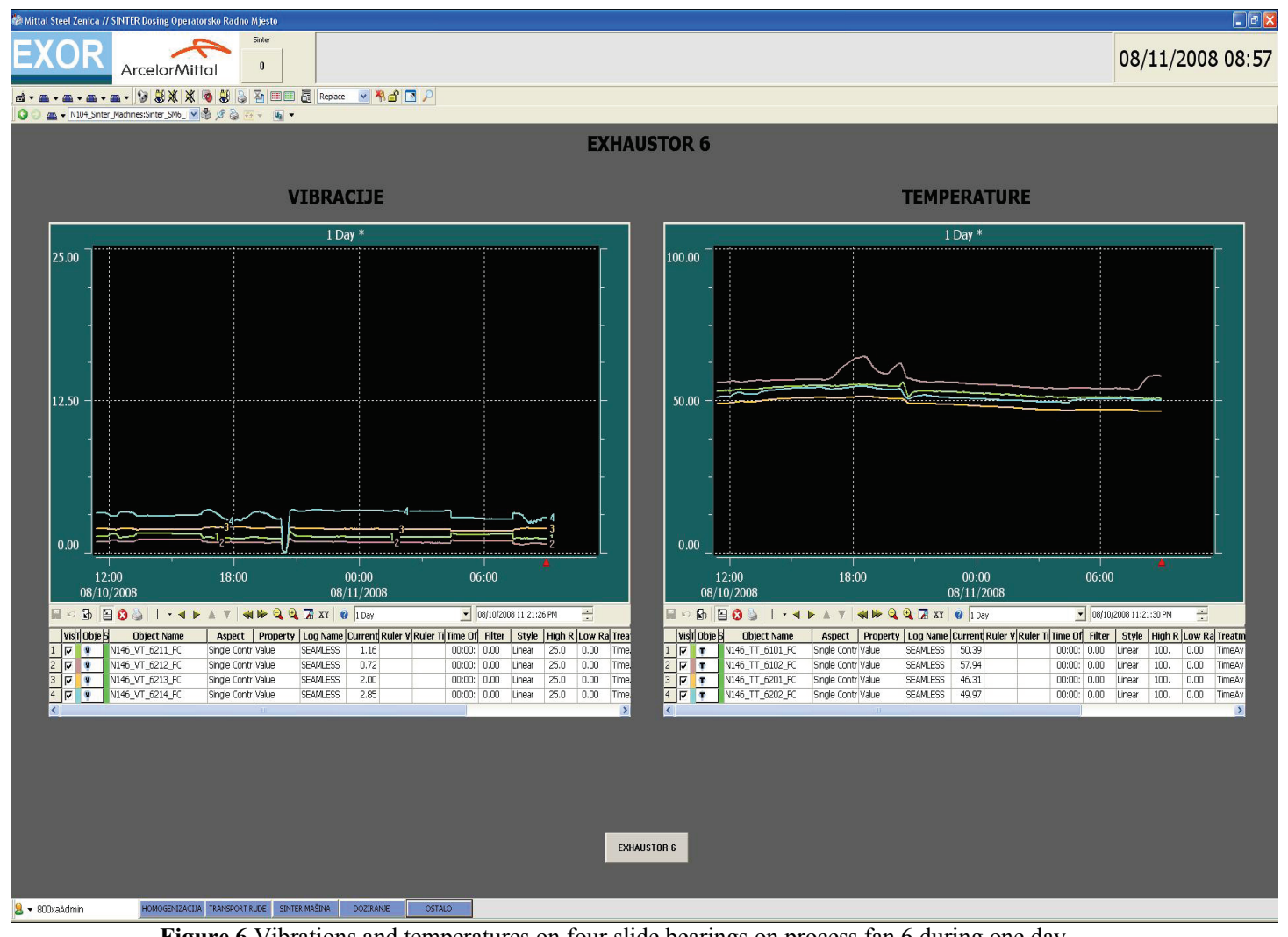

Figure 6 Vibrations and temperatures on four slide bearings on process fan 6 during one day

calculation and inference of the structure and casualty of the system using only output $y_{1}, y_{2}, \ldots, y_{n}$ measurment data (time series). This problem occurs in many scientific spheres, and in this paper it can be described as an identification and calculation of causative relations of mensural parameters in the system of process ventilators using temperature and vibration parameters. Granger's causative analysis uses multivariabile autoregressive (AR) 
modeling in the first step. For $n$ variable, $n \mathrm{AR}_{(p)}$ process $\boldsymbol{u}_{t}$ is specified by this model

$$
\sum_{k=0}^{p} \boldsymbol{A}_{k} \boldsymbol{u}_{t-k}=\varepsilon_{t} .
$$

$\boldsymbol{A}_{k}$ is $n \times n$ quadratic matrice, $k=0,1,2, \ldots, p$ is regressive coefficient, residual errors. In the first step, it is required to mathematically estimate series of $n \mathrm{AR}_{(p)}$ model. Two criteria are used: Bayes's Informational Criterion (BIC) and Akaike Informational Criterion $(A I C)$. In this case $N$ $=8$, and value $p=20$.

$$
\begin{aligned}
& B I K=-2 L+d \cdot \ln N, \\
& A J I K=-2 L+\frac{N(N+d)}{N-d-2},
\end{aligned}
$$

where: $L, N$ and $d$ are parameters of the model. Eqs. (2) and (3) are derivated from the theory of information.

\section{Nof ProvibTech}

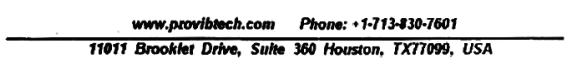

\section{CALIBRATION DATA}

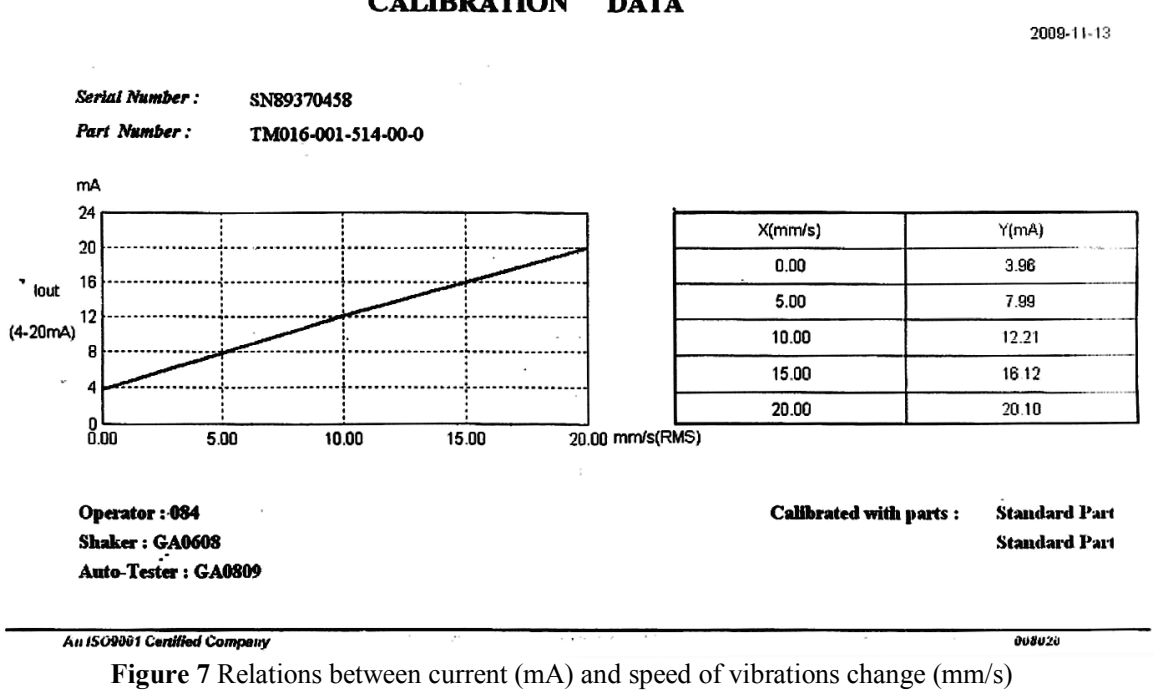

For mensural temperature and vibration data, three matrices $(16080 \times 8)$ are computed based on these expressions: AR models belong to series 20 .

Let's assume that two variables $X_{1}(t)$ and $X_{2}(t)$ generate time series with autoregressive models:

$$
\begin{aligned}
& X_{1}(t)=\sum_{j=1}^{p} A_{11, j} X_{1}(t-j)+\sum_{j=1}^{p} A_{12, j} X_{2}(t-j)+\xi_{1}(t), \\
& X_{2}(t)=\sum_{j=1}^{p} A_{21, j} X_{1}(t-j)+\sum_{j=1}^{p} A_{22, j} X_{2}(t-j)+\xi_{2}(t),
\end{aligned}
$$

where: $p$ - max number of observations; $A$ - coefficients of the model; $\xi_{1}, \xi_{2}$ - residual predictive errors for every time series.

If we decrease variations of residual predictive errors by introducing $X_{2}$ (or $X_{1}$ ) expressions in the first (or second) equation, then it can be said that $X_{2}$ (or $X_{1}$ ) Gcauses $X_{1}$ (or $\left.X_{2}\right)$. Formally, magnitude of these interactions between $X_{2}$ and $X_{1}$ can be described as a natural logarithm of ratio of residual predictive errors variations.

$$
F_{2 \rightarrow 1}=\ln \frac{\operatorname{var}\left(\xi_{1 R(12)}\right)}{\operatorname{var}\left(\xi_{1 U}\right)} .
$$

Causal density of dynamics of $\boldsymbol{X}$ system is defined as global measures of causal interactivity in the system [4, 5]. Causal density of system $\operatorname{cd}(\boldsymbol{X})$ is defined as arithmetic environment of all G-casualties of all system elements:

$c d(X)=\frac{1}{n(n-1)} \sum_{i \neq j} F_{X i \rightarrow X j} \mid X_{[i j]}$,

where $\boldsymbol{X}_{[i j]}$ is sub-system of $\boldsymbol{X}$. Causal density of system $\operatorname{cd}(\boldsymbol{X})$ is computed in interval $[0,1]$. Causal density $\operatorname{cd}(\boldsymbol{X})$ is a measure of dynamic complexity in system $\boldsymbol{X}$. High values of causal density $\operatorname{cd}(\boldsymbol{X})$, e.g. $0,8 \div 0,95$, indicate that elements of the system are globally dynamically coordinated, and at the same time dynamically distinctive; thus different elements in sub-systems $\boldsymbol{X}$ contribute in different ways to complexity of the system $\boldsymbol{X}$ [3]. For process ventilators, causal density $\operatorname{cd}(\boldsymbol{X})$ corresponds to "health" of process ventilators, where more $\operatorname{cd}(\boldsymbol{X})$ values indicate better condition of the system.

\section{Granger's causal graphs of process ventilators 4, 5, 6}

Causal density value is a constantly changeable form and it directly depends on treated continuous data base. Nominal value of causal density is $(0,5)[2 \div 5]$, which can be also higher, which directly depends on parameters measured through continuous monitoring. If this type of software and software for continuous monitoring are 
online software, then $\operatorname{cd}(\boldsymbol{X})$ is constantly being changed during the period of time. Values of causal density calculated in this paper are temporary values which are obtained based on considered data base. If vibration and temperature values are currently higher then $\operatorname{cd}(\boldsymbol{X})$ is lower and inverse. One-way causal relations are identified and marked with green lines and arrows and two-way causal relations are identified and marked with red lines. This means that vibration V1 causes temperatures T4, T3, T2, T1. Vibrations V1, V2, V3 have two-way casualty; the same thing is with vibrations V1 and V4 and temperatures $\mathrm{T} 1$ and $\mathrm{T} 3$ (Fig. 8). Causal density for process ventilator 4 (cd_4) is 0,4107 . That means that the current condition of process ventilator 4 is below nominal $[2 \div 5]$.

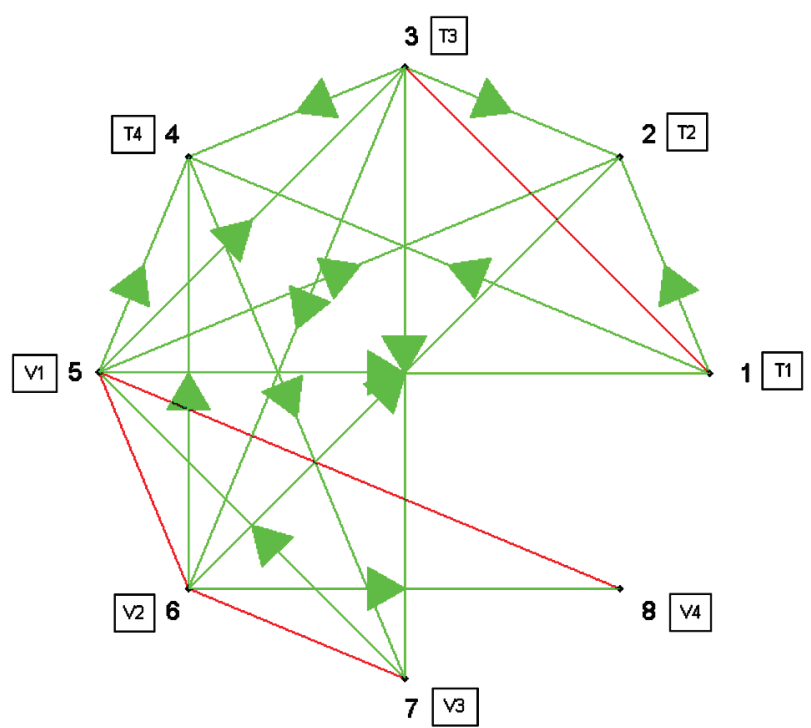

Figure 8 Granger' causal graph for process ventilator No 4

For process ventilator 5 , it is identified that vibrations V3 cause temperatures T4 and T2, while the temperature $\mathrm{T} 1$ has causal influence on vibrations V3 and V4. Temperatures T3 and T4 also have causal influence on vibrations V2 (Fig. 9). Vibrations V2 and V3 have twoway casualty. Causal density for process ventilator 5 (cd 5) is 0,4107. This also means that the current condition of process ventilator 5 is below nominal, [ $2 \div 5]$.

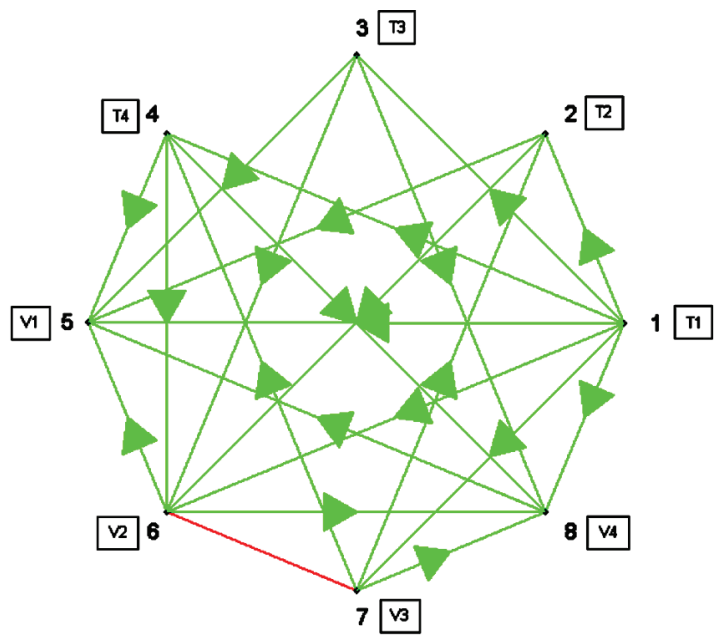

Figure 9 Granger' causal graph for process ventilator No 5
For process ventilator 6 , it is identified that vibrations $\mathrm{V} 1$ and V4 cause temperatures T4, T3, T2 and T1. Vibrations V1 and V2 have two-way casualty. It is interesting to mention that it is identified that vibrations V3 do not have any causal relations with other temperatures and vibrations (Fig. 10). Causal density for process ventilator 6 (cd_6) is 0,2143 . This also means that the current condition of process ventilator 6 is far more below nominal $[2 \div 5]$.

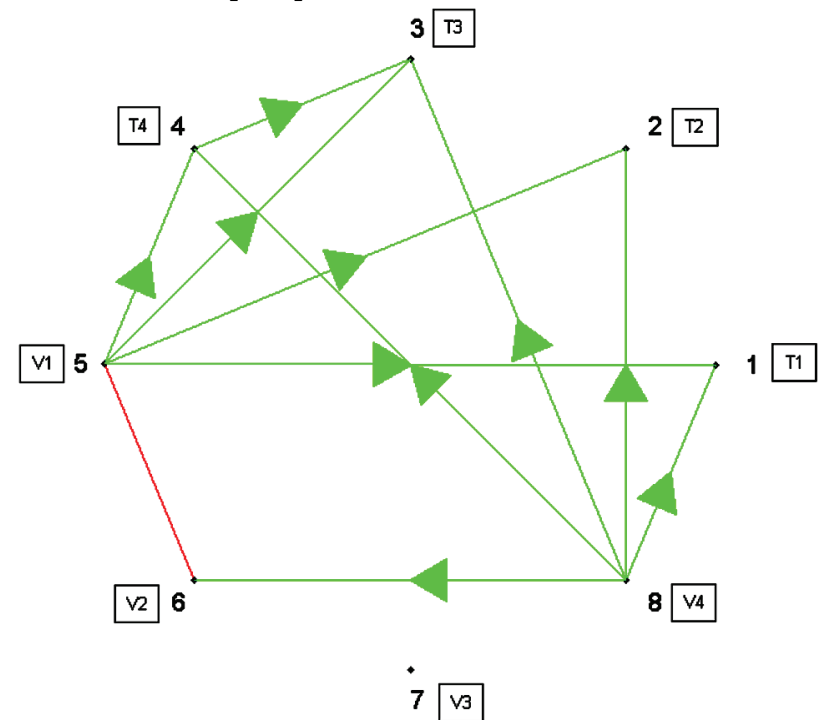

Figure 10 Granger' causal graph for process ventilator No 6

\section{Conclusions}

Based on presented method of automatic identification of causal knowledge and causal graphs for the system of process ventilators, by method of Granger's causal analysis, the following can be concluded:

- $\quad$ in technical diagnostic, this way of analysis can help to realize the character and legitimacy of temperature and vibrations behaviour i.e. operation of sliding bearings, el motor and impellor of process ventilators of this type (high power and high rotation speed)

- this approach enables, by means of continuous monitoring, introduction of software process for mechanical monitoring of process ventilators behaviour as well as performance of further analysis of condition and behaviour which are significant for their operation and maintenance

- in this way it is possible to learn about reciprocal relation and influence of temperature and vibrations between sliding bearings which are, together with other parts, creating one technical system such as process ventilators

- this approach makes it possible to learn about condition of process ventilators which is continuously being changed which further enables planning of proper maintenance, planning of costs and maintenance manpower, and all of that with the aim to improve maintenance of these facilities.

\section{References}

[1] Adamović, Ž. Tehnička dijagnostika, Zavod za udžbenike i nastavna sredstva Beograd, Beograd, 1998. 
[2] Barnett, L.; Seth, A. K. Behaviour of Granger Causality under filtering: Theoretical invariance and practical application. // Journal of Neuroscience Methods. 201, 2(2011), pp 404-419. DOI: 10.1016/j.jneumeth.2011.08.010

[3] Bressler, S. L.; Seth, A. K. Wiener-Granger Causality: A well established methodology. // NeuroImage. 59(2010), pp. 1-3.

[4] Seth, A. K. A MATLAB toolbox for Granger causal connectivity analysis. // Journal of Neuroscience Methods. 186, 2(2010), pp. 262-273. DOI: 10.1016/j.jneumeth.2009.11.020

[5] Seth, A. K. Granger Causal Connectivity Analysis: A MATLAB toolbox manual, School of Informatics, University of Sussex, 2011.

[6] Chen, H.; Gimenez, O. Causal graphs and structurally restricted planning. // Journal of Computer and System Science. 76, 7(2010), pp. 579-592. DOI: 10.1016/j.jcss.2009.10.013

[7] Khoo, L. P; Ang, C. L:; Zhang, J. A fuzzy-based genetic approach to the diagnosis of manufacturing system. // Engineering Applications of Artificial Intelligence. 13, 3(2000), pp. 303-310. DOI: 10.1016/S0952-1976(00)00003-8

[8] Taamouti A.; Bouzmarni, T.; El-Ghouch, A. Nonparametric estimation and inference for conditional density based Granger causality measures. // Journal of Econometrics. 180, 20(2014), pp. 251-264. DOl: 10.1016/j.jeconom.2014.03.001

\section{Authors' addresses}

Senad Alić, M.Sc.

University of Zenica

Polytechnical Faculty

Fakultetska 1, 72000 Zenica

Bosnia and Herzegovina

E-mail: senadalic@windowslive.com

Sabahudin Jašarević, Assoc. Prof. Ph.D. (contact author)

Safet Brdarević, Full Professor,

University of Zenica

Faculty of Mechanical Engineering

Fakultetska 1, 72000 Zenica

Bosnia and Herzegovina

E-mail: sjasarevic@mf.unze.ba

Mustafa Imamović, Associate Profesor,

Indir Jaganjac, M.Sc.

Arcelor Mittal Zenica

Bosnia and Herzegovina

E-mail: Mustafa.Imamovic@mittalsteel.com

E-mail: ijaganjac@yahoo.com 